\title{
Mediation for resolving family disputes
}

\author{
M. Kamenecka-Usova \\ University of Latvia, Rīga, Latvia; Erasmus University Rotterdam, Rotterdam, The Netherlands
}

\begin{abstract}
Nowadays the understanding of the institute of marriage and its importance in the society has changed. Marriage is no longer assumed to be a commitment for a lifetime. As the principle of equality has replaced hierarchy as the guiding principle of family law it gave more grounds for family disputes and it became socially acceptable to leave marriages that are intolerable or merely unfulfilling. The aim of this article is to suggest an alternative dispute resolution method-mediation as a worthy option for resolving family conflicts.
\end{abstract}

\section{Introduction}

The institute of marriage is an important pillar of a healthy society. This statement seems quite obvious, as well as pros that family can give to both individuals committed to each other and, of course, children, born in the family.

However, nowadays this idea is doubted and questioned very often. Marriage is no longer assumed to be a commitment for a lifetime.

For example, according to Herbert Jacob, in the early nineteenth century, wives were clearly subordinate to their husbands. Upon marriage, a woman lost her maiden name and took up the identity of her husband. Her name change signified not only a new identity but also subordination to her husband in many matters. For example, both custom and law required a wife to live wherever her husband chose. In return, wives were expected to maintain the home and to submit to their husband's sexual demands. Finally, wives originally had no control over property, even when they brought it with them into marriage [1].

But today, the principle of equality has replaced hierarchy as the guiding principle of family law [1]. Committee on the Elimination of Discrimination against Women (CEDAW) in its General Recommendations brings the Committee's approach to equality in the family into the 21 st Century and states that women's equal rights to property must be globally recognized regardless of its form, and in all world regions and legal systems [2].

Formerly, adultery was grounds for divorce, sometimes the only ground. Now, with nofault divorce, whether the spouse has committed adultery is irrelevant to whether spouses can divorce and generally has no bearing on other issues in a divorce [3].

Given the importance of a "partnership" basis of marriage for many people, it became socially acceptable to leave marriages that are intolerable or merely unfulfilling. Movements promoting children's rights and fathers' rights also contributed to increased family conflicts [3].

The question is, whether a suit to court is an optimal path to choose in order to resolve frequently occurring family disputes?

When parties are unable to resolve their dispute through discussion and negotiation, a logical next step is to seek the assistance of a third party to facilitate communication and the search for a solution [4]. Such step can lead parties in dispute, i.e., spouses, to the mediation. 
The aim of this article is to suggest an alternative dispute resolution method-mediation as a worthy option for resolving family conflicts.

\section{What does "mediation" stand for?}

Mediation is an alternative dispute resolution mechanism (ADR). The goal of mediation is for the parties to reach a voluntary settlement which is then reduced to writing and becomes a contract [5]. In this process a neutral third party (mediator) helps disputants to come to consensus on their own [6] by assisting the parties to find a resolution to their conflict in a sustainable and self-determined way [7].

\section{The advantages of the mediation}

Mediation is constructive and involves the chance for personal development and social growth for the parties of the conflict. The principle of voluntariness and the development of the solution by the parties themselves carry with them the expectation of substantive justice. Additionally, mediation holds the promise of cost-efficient and faster dispute resolution compared with other methods therefore, parties might opt for mediation because they expect mediation to be quicker and cheaper than court proceedings. Another reason to prefer mediation over court proceeding may be confidentiality and the wish to preserve a good relationship with the other party [8], what is especially important in family disputes ${ }^{1}$. Therefore, regarding all above said, opting for mediation in order to resolve family conflicts shall meet satisfying result.

\section{The historic appearance of mediation in family law}

It is worth to mention that much of the structuring of the mediation process, which prepares the process to become institutionalized and legitimized as a regular part of the legal landscape began in the divorce context in the mid 1970's with more people seeking the dissolution of marriage and finding the legal process particularly cumbersome. Not surprisingly, this social phenomenon began in California, which was among the first in the United States of America, and the world for that matter, to formally include marriage conciliation and mediation as court services. Shortly thereafter, a private market for divorce mediation emerged throughout the USA, based on the work of O.J. Coogler, an Atlanta lawyer, who structured the mediation process so that it could be replicated and taught. The structuring of the process allowed it to spread America wide and abroad by the end of the 1980's. This development of a mediation structure and format allowed the process to be applied and adapted beyond divorce and family matters to many other dispute context and the core of the model remains in use [8].

Speaking about Americas vast experience, in the last decade, California mandated conciliation (here it is used by Rau, Sherman and Peppet as a synonym of mediation) for issues of child custody or visitation as a prerequisite to a divorce trial, and judges in some other states have imposed this requirement through court rule [4].

Therefore, we can see that originally mediation was used to resolve family disputes because it met the requirements and needs of that time. And nowadays, according to the author, that needs to be only escalated, and California's practice proves the viability of the idea where family disputes are resolved with the help of mediation.

\footnotetext{
${ }^{1}$ It should be noted, that each conflict needs to be evaluated on an individual basis and the best suited dispute resolution mechanism has to be chosen.
} 


\section{Mediation - more than just a dispute resolution method}

As it was mentioned by Currie, mediation is not a natural extension of the practice of law, because mediation permits a broader definition of conflict as well as a more complete approach to its resolution [9]. That is why some family-law mediators bring a "therapeutic" [10] dimension to mediation, encouraging the parties to recognize and confront the underlying emotional issues and, where appropriate, to work on their relationship. Family mediation generally devotes considerable attention to non-legal emotional and relationship issues [4] what makes it more than just a dispute resolution method and in the context of family disputes, mediation can lead to a reconciliation and reunification of both parties.

In general, we can name two styles of mediation processes, i.e. joint sessions and a "caucus". The first one allows each side to hear the other's view and a prospect on the dispute but the second one being a private meeting between the mediator and just one of the parties in dispute that takes place out of hearing of the other party. According to Silbey and Merry, the purpose of "caucus" session is to uncover issues that parties were reluctant to discuss in the joint session [10]. Taking into account the emotional side of family disputes that often prevents the parties from soberly assessing the situation and reaching a consensus, caucus seems to be a more effective style of mediation process. Rau, Sherman and Peppet also emphasize that face-to-face mediation is not always viewed as desirable in divorce mediation, and "shuttle mediation", with only a limited face to face meeting between the parties, has attracted support in certain divorce situations [4].

The complexity of issues that must be resolved concerning child custody, property division, and future relationships, plus the confusion and distraction caused by family miscommunication, are often cited as warranting a more activist mediator role [4]. According to author, especially in family disputes with its very special emotional side, the professionalism of the mediator should be unquestionable and doubtless as the neutrality of the mediator plays a big role and his personal life experience should not affect his attitude towards the parties and harm the communication process.

\section{Conclusion}

Mediation in family disputes is an attempt to get to the core of the conflict and resolve it amicably. Mediation can significantly diversify and facilitate family dispute resolution procedures, as well as help separating couples to reach agreements that are in the best interests of their children and in some cases even prevent couples from separating.

\section{References}

[1] H. Jacob, Silent Revolution: The Transformation of Divorce Law in The United States (Chicago University Press, Chicago, 1988) p. 3-5.

[2] Committee on the Elimination of Discrimination against Women http://www.ohchr.org/EN/NewsEvents/Pages/Equalityinfamilyrelations recognizingwomensrightstoproperty . aspx accessed on 25.05.15.

[3] J. Lande, The Revolution in Family Law Dispute Resolution. Missouri University Legal Studies Research Paper Series, Research Paper No. 2012-10, 24 J. of The American Academy Of Matrimonial Lawyers 411 (2012) p. 412-413.

[4] A. S. Rau, E. F. Sherman, S. R. Peppet, Mediation and Other Non-Binding ADR Processes. (Foundation Press, 2002) p. 1-5.

[5] K. V. W. Stone, Alternative Dispute Resolution. Encyclopedia of Legal History, UCLA School of Law Research Paper 04-30, p. 1. 
[6] Mediation secrets for better business negotiations, Harvard Law School Negotiation Special Report 7, p. 1. Accessed at www.pon.harvard.edu on 16.09.14.

[7] F. Steffek, Mediation in the European Union: An Introduction (Cambridge, 2012) p. 2

[8] B. Robert, The Natural History of Negotiation and Mediation: The Evolution of Negotiative Behaviors, Rituals and Approches (2012). Accessed at www.mediate. com/articles/NaturalHistory.cfm on 17.03.15.

[9] C. Currie. Should a mediator also be a lawyer? Accessed at http://www . mediate.com/articles/currie.cfm on 27.05.15.

[10] S. S. Silbey and S. E. Merry, Mediator Settlement Strategies, J. Law \& Policy 8 (1986) p. 10-19. 